\title{
Effect of a calcium-energy supplement drink at calving on lactation performance: Milk yield and composition, odds to reach a next lactation, and calving interval
}

\author{
Jean-Baptiste Daniel, ${ }^{*} \dagger$ ๑ Juliette N. Wilms, ${ }^{*}$ ๑ Jan H. Mica, and Javier Martín-Tereso \\ Trouw Nutrition R\&D, P.O. Box 299, 3800 AG, Amersfoort, the Netherlands
}

\section{ABSTRACT}

Supplementation of Ca products to cows after calving is common in calving protocols. This study evaluated the effect of a Ca-energy drink voluntarily consumed on milk yield and composition, odds to reach a next lactation, and calving interval. This prospective randomized study included a blinded placebo and was conducted in 10 commercial dairy farms that included 504 Holstein dairy cows. Cows were blocked within farm by calving sequence and parity (primiparous or multiparous). Within each block of 2 animals, cows were randomly assigned to 1 of 2 treatments: a Ca-energy supplement drink (CAE, $\mathrm{n}=255$ ) providing $45 \mathrm{~g}$ of $\mathrm{Ca}$ and other components (dextrose, lactose, protein, fat, other minerals and vitamins), a placebo (i.e., $100 \mathrm{~g}$ of cellulose and $20 \mathrm{~g}$ of dextrose; CON, $\mathrm{n}=249$ ), both strictly offered to the animals for voluntary consumption. Treatments were offered mixed in $20 \mathrm{~L}$ of water within $3 \mathrm{~h}$ after calving. Milk data were analyzed using 2 approaches. The first, most classical, evaluated the effect of the treatments on observed milk data, whereas the second approach evaluated the effect on milk residuals (i.e., the difference between observed milk data and a prediction made by a herd test-day model). Eighty-one percent of the CAE cows fully consumed the treatment, whereas only $50 \%$ of CON cows did. No differences were detected for observed milk yield, nor for composition in multiparous cows. The only production effect observed on multiparous cows was a treatment by time interaction for milk fat yield, reflecting greater yield for CAE cows between 100 and 150 d in milk only. However, primiparous cows receiving $\mathrm{CAE}$ had increased milk $(+0.8 \mathrm{~kg} / \mathrm{d})$ and component yields (i.e., $+40 \mathrm{~g} / \mathrm{d}$ of protein) compared with CON cows. These effects were more evident when milk and milk components residuals data were analyzed (i.e., $+1.5 \mathrm{~kg} / \mathrm{d}$ for milk yield and

Received October 6, 2020.

Accepted May 9, 2021.

*These authors contributed equally to this work.

†Corresponding author: Jean-Baptiste.Daniel@trouwnutrition.com
$+57 \mathrm{~g} / \mathrm{d}$ of protein). This was achieved with a herd test-day model that allowed milk and milk components data to be adjusted for environmental and genetic factors (i.e., farm effect, time effect, age at calving, parity, stage of lactation, breeding value). The treatment had no effect on the probability of reaching the next lactation (i.e., $72 \%$ of CAE cows had a next calving against $69 \%$ in CON). Primiparous cows receiving CAE had a longer calving interval compared with $\mathrm{CON}$ cows. At $400 \mathrm{~d}$ after the application of the treatment, $65 \%$ of CAE primiparous cows had a next calving, whereas $81 \%$ of CON primiparous cows had calved already. The supplementation of the tested oral Ca-energy solution at calving did not increase the probability to reach a next lactation for neither primiparous or multiparous, but positively influenced milk yield and milk component yields for primiparous.

Key words: transition, herd test-day model, commercial dairy herd

\section{INTRODUCTION}

Although incidence of clinical hypocalcemia is low in modern production systems, subclinical hypocalcemia affects between 41 and $54 \%$ of multiparous cows (Reinhardt et al., 2011). Cows with subclinical hypocalcemia are at a greater risk for calving-related disorders (Chapinal et al., 2011; Martinez et al., 2012), impaired reproductive functions (Caixeta et al., 2017), and culling (Roberts et al., 2012). Nevertheless, whereas milk fever has been associated with a milk yield loss from 1.1 to $2.9 \mathrm{~kg} / \mathrm{d}$ for the first 4 to $6 \mathrm{wk}$ after calving by Rajala-Schultz et al. (1999), subclinical hypocalcemia does not necessarily result in a milk yield reduction (Rowlands and Lucey, 1986; Østergaard and Larsen, 2000). In fact, subclinical hypocalcemia has been associated with higher milk yields when factors such as health status are considered in the contrast (Jawor et al., 2012). These discrepancies on the relationship between blood total $\mathrm{Ca}(\mathbf{t C a})$ concentrations and milk yield may also be explained by the time of blood sampling relative to calving. Within the first $24 \mathrm{~h}$ after calving, Neves 
et al. (2018) observed a negative correlation between blood tCa and milk yield for both primiparous and multiparous cows, whereas at 4 DIM, the relationship was positive for multiparous cows. Consistently, McArt and Neves (2020) observed that cows that experienced transient hypocalcemia had greater milk production than normocalcemic cows. In contrast, cows with delayed or persistent hypocalcemia did not differ in milk production compared with normocalcemic cows.

Short-term postpartum management strategies to prevent or mitigate hypocalcemia are often integrated in farm protocols for transition management and include oral Ca supplements (Sampson et al., 2009) as well as subcutaneous (Goff, 1999) or i.v. Ca infusions (Blanc et al., 2014). In contrast to i.v. Ca infusions, providing oral Ca supplements sustains blood Ca concentrations within $24 \mathrm{~h}$ after calving and are unlikely to result in an exaggerated calcemic signal right after administration (Blanc et al., 2014; Wilms et al., 2019). Boluses including $\mathrm{CaCl}_{2}$ are the most common oral Ca supplements. However, some unwanted side effects have been associated with the use of $\mathrm{CaCl}_{2}$, which may result in epithelial damage during administration (Thilsing-Hansen et al., 2002). Unlike $\mathrm{CaCl}_{2}$, supplements including $\mathrm{CaCO}_{3}$ as a $\mathrm{Ca}$ source do not represent a risk to irritate the mucous lining of the gastrointestinal tract and offer the possibility to avoid drenching [J. N. Wilms, J. B. Daniel, J. Martin-Tereso, Y. Han, S. van Kuijk (Trouw Nutrition R\&D, the Netherlands), A. Klop, and R. Goselink (Wageningen University, the Netherlands), unpublished data]. Therefore, $\mathrm{CaCO}_{3}$ formulations allow for a voluntary oral administration, potentially improving animal welfare aspects of the calving protocol. However, the ability of $\mathrm{CaCO}_{3}$ to maintain or elevate blood Ca concentration is not well described. Goff and Horst (1993) evaluated the effects of several Ca sources on plasma $\mathrm{Ca}$ concentration responses within the first $6 \mathrm{~h}$ after administration. Calcium carbonate was not effective within this timeframe at raising plasma Ca. However, when this response was evaluated over a longer period (48 h), oral Ca supplement containing $\mathrm{CaCO}_{3}$ (45 g of $\mathrm{Ca}$ ) was shown to be at least as effective as a $\mathrm{Ca}$ bolus containing $\mathrm{CaCl}_{2}$ (43 $\mathrm{g}$ of $\mathrm{Ca}$ ) in maintaining $\mathrm{Ca}$ homeostasis around calving [J. N. Wilms, J. B. Daniel, J. Martin-Tereso, Y. Han, S. van Kuijk (Trouw Nutrition R\&D, the Netherlands), A. Klop, and R. Goselink (Wageningen University, the Netherlands), unpublished data]. This could highlight a different dynamic of $\mathrm{Ca}$ absorption between the 2 sources of Ca.

Few experiments have investigated the effect of oral Ca supplements at calving on lactation performance. Some of these studies (Stevenson et al., 1999; Melendez et al., 2003) showed no milk yield response to Ca supplementation at calving. The absence of milk response could in part be related to the interactions reported with previous lactation milk yield (Oetzel and Miller, 2012; Martinez et al., 2016), previous lactation length (Valldecabres and Silva-del-Río, 2021), as well as parity and BCS (Leno et al., 2018). The highest producing cows seem to be more prone to respond with greater milk yield when supplemented with Ca boluses at calving (Oetzel and Miller, 2012; Martinez et al., 2016), as well as cows with longest previous calving intervals (Valldecabres and Silva-del-Río, 2021). Some of these studies also investigated the effect of Ca supplementation on fertility and show heterogeneous results, with no effect on reproduction (Melendez et al., 2003; Valldecabres and Silva-del-Río, 2021), reduced intervals between planned start of mating and conception (Stevenson et al., 1999), or improvement of pregnancy per AI ratio for multiparous cows but lower ratio for primiparous (Martinez et al., 2016).

In the current study, we evaluated the effects of a Ca-energy supplement drink in relation to a control liquid placebo at calving on lactation performance of primiparous and multiparous cows, specifically milk yield and composition, odds to reach a next lactation, and calving interval.

\section{MATERIALS AND METHODS}

\section{Animals and Experimental Design}

This prospective, randomized and blind study was conducted in 10 commercial dairy farms located in the Netherlands (Table 1). The prerequisites for the farms to be enrolled in the study were (1) their adherence to the monthly milk control of the cattle improvement cooperative organization (CRV BV), (2) their willingness to follow instruction about treatment administration, and (3) that no other Ca or Ca-energy supplement (i.e., voluntary oral consumption or forced-fed bolus) were offered at calving. A total of 613 Holstein dairy cows were enrolled in the study from September 2016 to October 2017 upon calving (see Supplemental File S1, https://figshare.com/articles/figure/20210602 _Manuscript_CRV_Reviva_-_Supplemental_Files _docx/14716365). Each cow was followed for a duration of 18 mo. Cows were blocked within farms by calving sequence and parity (primiparous or multiparous). To ensure adequate randomization of treatments within a block, producers enrolled in this experiment were given treatment assignment sheets, for both primiparous and multiparous cows, giving clear guidance on sequence of treatments to be assigned as cows were calving (see Supplemental File S2, https://figshare.com/ articles/figure/20210602_Manuscript_CRV_Reviva --_Supplemental_Files_docx/14716365). In this way, 
within each block of 2 animals, cows were randomly assigned to 1 of 2 treatments, including a Ca-energy supplement drink (CAE, $\mathrm{n}=312$ ) or a control liquid placebo (CON, n = 301), offered for voluntary consumption. To ensure proper implementation of the protocol, farms were visited at least once in the course of the experiment. Treatments were prepared in individual doses and were blinded to the farmer by assigning a letter (A or B) to each treatment. The CON treatment consisted of $100 \mathrm{~g}$ of highly purified food grade cellulose pulp (Jelucel PF 90, JELU Werk) and $20 \mathrm{~g}$ of dextrose to be mixed in $20 \mathrm{~L}$ of water. The inclusion of cellulose pulp and dextrose were justified so that farmers would be blinded to treatments. If only water was provided, that would not have been possible. Such low amount of fiber and energy in the form of dextrose is not expected to result in measurable physiological response. Cows in the CAE group were individually offered $1 \mathrm{~kg}$ of a Caenergy supplement (Farm-O-San Reviva, Trouw Nutrition) mixed in $20 \mathrm{~L}$ of water and offered for voluntary consumption. The supplement provided a total of $45 \mathrm{~g}$ of $\mathrm{Ca}$ from $\mathrm{CaCO}_{3}(93.2 \%$ of $\mathrm{Ca})$, Ca formate $(5 \%$ of $\mathrm{Ca})$, and $\mathrm{Ca}$ propionate $(1.8 \%$ of $\mathrm{Ca})$. In addition to the Ca components, the product also included dextrose $(31.8 \%)$, lactose $(15.5 \%)$, protein $(6.7 \%)$, fat $(4.7 \%)$, others macrominerals (in $\mathrm{g} / \mathrm{kg}$ of supplement: $51 \mathrm{Cl}$, $47 \mathrm{Na}, 9 \mathrm{~K}, 5 \mathrm{P}$, and $0.6 \mathrm{Mg}$ ), trace minerals (in $\mathrm{mg} /$ $\mathrm{kg}$ of supplement: $200 \mathrm{Fe}, 190 \mathrm{Mn}, 20 \mathrm{I}$, and $2 \mathrm{Se}$ ), and vitamins (in IU: 80,000 vitamin A, 18,000 vitamin $\mathrm{D}$, and 2,700 vitamin $\mathrm{E}$ ). Both aqueous suspensions were prepared in a bucket containing $10 \mathrm{~L}$ of warm water $(40$ to $45^{\circ} \mathrm{C}$ ) by mixing thoroughly. Once dissolved, $10 \mathrm{~L}$ of cold water were added to achieve a final temperature of 25 to $30^{\circ} \mathrm{C}$. Administration of the treatments was always supervised to prevent another cow from drinking the liquid supplement. Supervision was also critical to record if cows consumed the treatment fully or not. As a consequence, all calving that could not be supervised were not considered for the experiment. The bucket was placed in front of the cow within $3 \mathrm{~h}$ after parturition. Cows were allowed to consume the suspension for 15 min. Both suspensions were offered only once and were never drenched.

\section{Measurements and Statistical Analysis}

With the exception of consumption of the treatment (fully consumed or not), all other data were obtained through the standard milk control system of CRV. Farm identification number from each cow enrolled, as well as calving date and parity group (either primiparous or multiparous) were collected from each farm, and this information was used to retrieve milk data, calving and culling dates, as well as subclinical ketosis diagnosis ob- tained from CRV. From the original 613 cows enrolled, 504 cows were reliably identified. For the others 109 cows, either the identification number used at the farm could not be matched with the unique lifetime identification number (consisting of 2 letters "NL" and 9 digits), or the calving date and parity number retrieved by CRV were not consistent with information collected on farm. Therefore, all the analyses were restricted to the 504 cows, with 255 cows in the CAE group and 249 in the CON group. The full details of number of cows used per farm, and for each treatment and parity is given in Table 1. Eleven farms were initially enrolled, but one dairy farmer refused to sign the data-sharing agreement, and thus cows from farm 4 could not be used for any analysis. Among enrolled cows, 144 were in first lactation and 366 in second or more lactations. Among multiparous cows, the average parity was 3.2 (41\% second lactation, $24 \%$ third lactation, $18 \%$ fourth lactation, and $17 \%$ fifth and above lactations) for the CAE group and 3.4 (41\% second lactation, 21\% third lactation, $18 \%$ fourth lactation, and $21 \%$ fifth and above lactations) for the CON group. The number of complete blocks was 225 (i.e., $81 \%$ of total block), and among those, $99 \%$ were composed of cows with calving date difference less than $20 \mathrm{~d}$ (see Supplemental File S3, https://figshare.com/articles/figure/20210602 _Manuscript_CRV_Reviva___Supplemental_Files _docx/14716365). For milk yield and composition data, due to observed interaction between treatment and parity, all analyses were run separately for primiparous and multiparous cows. Studying the effect of parity among multiparous cows was not possible as it would haved involved comparison of treatment within block. For other analysis (incidence of subclinical ketosis, odds to reach a next lactation, and calving interval), analysis were first run with all cows. In case of a significant interaction between treatment and parity was observed $(P<0.05)$, analyses were also run separately for primiparous and multiparous.

Voluntary Consumption of the Treatments. Each farmer reported if the liquid supplements were fully consumed or not. This data was then analyzed by logistic regression using the GENMOD procedure in SAS (version 9.4, SAS Institute) with binomial distribution and the logit link function.

Milk Yield and Composition. Milk yield, milk component yields, and concentrations were obtained from the CRV test-day milk records. The test-day sampling was done monthly for all 10 farms enrolled and was performed over 2 consecutive milkings: an evening milking and the morning milking of the next day. The milk composition of all test-day samples was analyzed according to regular test-day procedures in the laboratory of Qlip NV (Zutphen, the Netherlands). Briefly, 
Table 1. Number of cows enrolled in the experiment per farm, parity group, and treatment

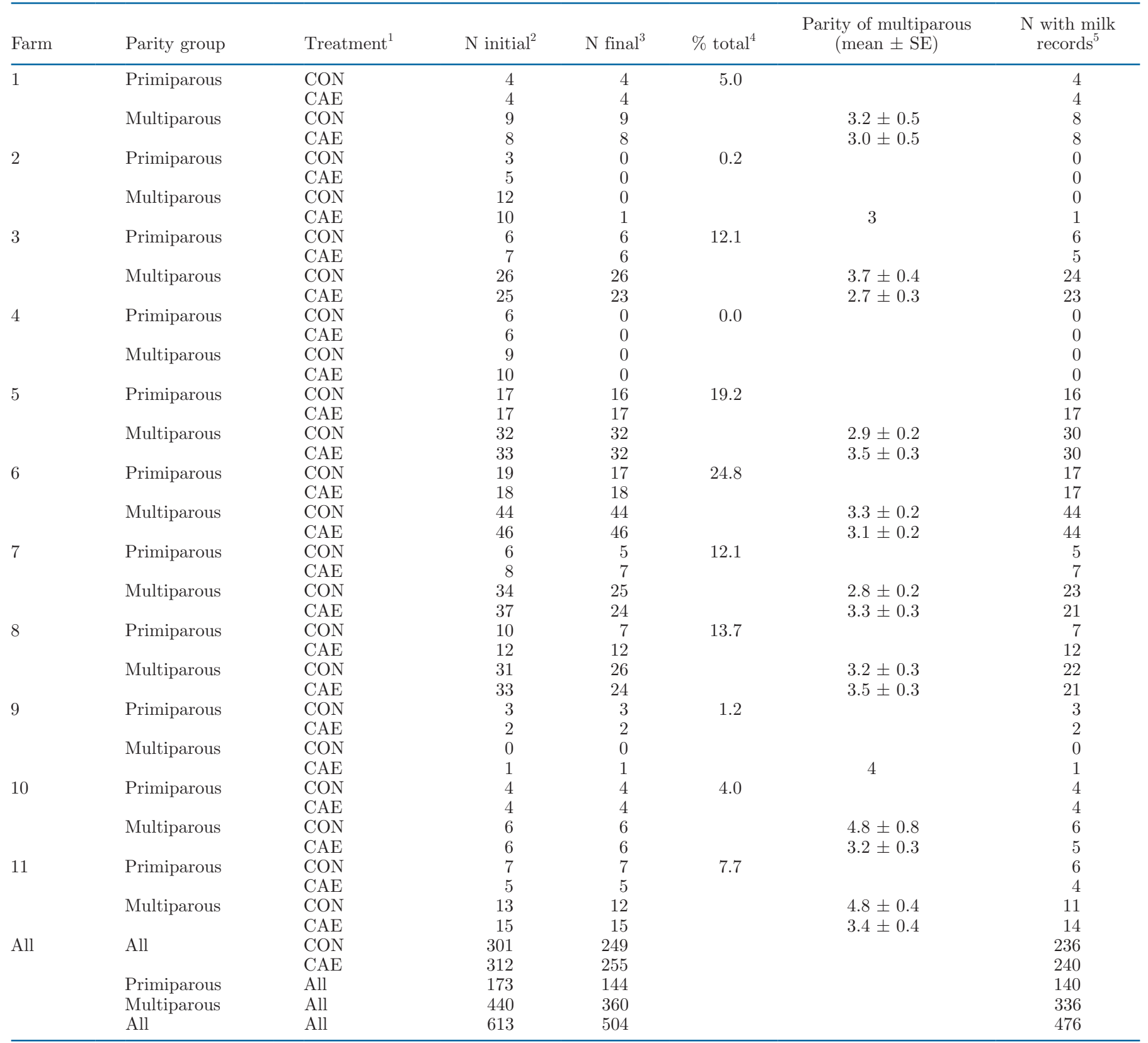

${ }^{1}$ Treatments included a Ca-energy supplement drink (CAE; $\mathrm{n}=240 ; 45 \mathrm{~g}$ of Ca and dextrose, lactose, protein, fat, other minerals, and vitamins) or a placebo $(\mathrm{CON} ; \mathrm{n}=236 ; 100 \mathrm{~g}$ of cellulose and $20 \mathrm{~g}$ of dextrose), offered for voluntary consumption. Treatments were offered mixed in 20 $\mathrm{L}$ of water within $3 \mathrm{~h}$ after calving for a total duration of $15 \mathrm{~min}$.

${ }^{2}$ Number of cows enrolled in the experiment and fed the treatment.

${ }^{3}$ Number of cows considered for statistical analysis (i.e., analysis of voluntary consumption, odds to reach next lactation). A total of 109 cows were removed because cow identification could not be confirmed. See text for details.

${ }^{4}$ Percentage of experimental cows in each farm ( $\mathrm{N}$ final per farm divided by 504, \%).

${ }^{5}$ Number of cows with available milk records and used for milk yield and milk composition analysis. A total of 28 cows (i.e., 504 minus 476 ) had no milk records. Most of them were culled before 30 DIM $(\mathrm{n}=20$, with average culling date of 13 DIM). The other 8 cows were culled much later $(\mathrm{n}=4$, culled at 54, 192, 263, and 415 DIM) or had a next calving ( $\mathrm{n}=4$ with calving interval between 406 and 425 DIM).

test-day milk samples were gently preheated to $40^{\circ} \mathrm{C}$ and mixed before analysis with a MilkoScan FT600 (Foss Analytical A/S). This Fourier Transform InfraRed in- strument was used according to the instructions of the manufacturer with operational calibrations for fat (ISO 1211, IDF1; ISO, 1999), protein (ISO 8968, IDF 20-1; 
ISO, 2001), and $\beta$ hydroxybutyric acid (BHBA) and acetone (de Roos et al., 2007). Because of early culling, some cows had no milk records $(\mathrm{n}=13$ for $\mathrm{CON}$ and $\mathrm{n}$ $=15$ for CAE), and thus the final number of cows used for all milk analysis was 476. In addition, the analysis was restricted to milk data from calving until $249 \mathrm{~d}$ postcalving, as it has been shown that the concurrent pregnancy in lactating dairy cows causes a depression in milk yield in the last 18 wk of pregnancy (Coulon et al., 1995). Therefore, the objective was to assess any effects on milk yield independently from reproduction performance. Further, to create homogeneity in DIM records between cows, data were averaged in 5 periods of $50 \mathrm{~d}$ each $(0-49,50-99,100-149,150-199$, and 200-249). Milk yield, fat- and protein-corrected milk (FPCM), milk component yields, and concentrations were analyzed as repeated measurements with PROC MIXED of SAS according to the following model:

$$
\begin{gathered}
\mathrm{Y}_{\mathrm{ijk}}=\mu+\text { TREAT }_{\mathrm{i}}+\text { DIM }_{\mathrm{j}}+\text { TREAT }_{\mathrm{i}} \times \mathrm{DIM}_{\mathrm{j}} \\
+ \text { BLOCK }_{\mathrm{k}}+\varepsilon_{\mathrm{ijk}},
\end{gathered}
$$

in which $\mathrm{Y}$ is the dependent variable, $\mu$ is the overall mean, and $\varepsilon_{\mathrm{ijk}}$ is the residual error. The model included the fixed effects of treatment $\left(\mathrm{TREAT}_{\mathrm{i}} ; \mathrm{i}=1\right.$ or 2 ), DIM category $\left(\mathrm{DIM}_{\mathrm{j}} ; \mathrm{j}=1\right.$ to 5$)$, the interaction between treatment and DIM, and the random effect of block $\left(\mathrm{BLOCK}_{\mathrm{k}} ; \mathrm{k}=1\right.$ to 273$)$. The cow was considered the experimental unit, and DIM was included as a repeated statement. The autoregressive (1) covariance matrix was used (Sawalha et al., 2005). If the interaction between treatment and DIM was not significant $(P$ $>0.05$ ), the interaction was removed in the final model. The FPCM (corrected to $4.0 \%$ fat and $3.3 \%$ protein; $\mathrm{kg} / \mathrm{d})$ was calculated as milk yield $(\mathrm{kg} / \mathrm{d}) \times[0.377+$ $0.116 \times$ fat $(\%)+0.06 \times$ protein $(\%)]$. Finally, normality of residuals of all models was evaluated with the Shapiro-Wilk test using PROC CAPABILITY of SAS.

A second approach to data analysis was also performed using the residual milk data obtained by subtracting the observed from the predicted milk data estimated by the herd test-day model from CRV (de Roos et al., 2004, see Supplemental File S4 for more details, https://figshare.com/articles/figure/20210602 _Manuscript_CRV_Reviva_-_Supplemental_Files _docx/14716365). The use of these predictive values allowed us to correct for many fixed effects and their interactions known to affect milk performance (i.e., farm effect, time effect, age at calving, parity, stage of lactation, breeding value). In this way, an independent sample with 4,572 cows not enrolled in the study was used to estimate all the fixed effects used to predict milk performance data from the 504 cows in study and acted as a cohort for the 2 treatments in the study. All cows from the cohort calved during the enrollment period of cows in the study (i.e., from September 2016October 2017). Available milk data from these 504 cows before the experiment were also serving that purpose. The consideration of all these effects into the statistical model was intended to increase the experimental power to contrast effects of the treatment.

The herd test-day model provided residual values for performance parameters. A residual value for milk yield not different from zero indicated that observed milk yield was according to expectation. However, a positive (or negative) residual would indicate a production above (or below) the expected value when considering all available factors in the model. Therefore, the comparison between the residual values from a given treatment to zero would indicate if the application of this treatment was correlated with an increase or decrease in milk yield. In the present experiment, to be able to infer causal effects of the treatment, these residuals milk data were analyzed using the same model as presented above for observed milk data, which included the randomized block design to contrast with a control.

Incidence of Subclinical Ketosis. For cows that were between 5 and 30 DIM at a milk production registration (i.e., monthly milk control), concentrations of milk acetone and BHBA were used together with season, parity, and the fat-protein ratio in milk as a proxy for subclinical ketosis (van der Drift et al., 2012b). Each cow was classified based on its individual test-day record as nonketotic or ketotic. This model showed $82.4 \%$ sensitivity and $83.8 \%$ specificity for the detection of hyperketonemia (within the first $60 \mathrm{DIM}$ ), defined as cows with plasma BHBA above 1,200 $\mu \mathrm{mol} / \mathrm{L}$ (van der Drift et al., 2012b).

From the 504 cows used in the study, 335 were evaluated for this subclinical ketosis proxy between $\mathrm{d} 5$ and 30 of the lactation (i.e., $66.5 \%$ of the cows, 166 cows for CAE, and 169 for CON). About half of the cows had more than 1 evaluation during this period, and the data set was consolidated to a single observation for these cows, considering a single observation of presence of subclinical ketosis for that animal as a positive. Data were then analyzed using logistic regression (GENMOD procedure in SAS, with binomial distribution and the $\log$ link function). The risk ratio (RR) with $95 \%$ confidence interval is reported.

Odds to Reach a Next Lactation and Calving Interval. Odds to reach a next lactation and calving interval were analyzed with multivariable survival analysis using Cox's proportional hazards regression (the PHREG procedure in SAS). In the analysis of odds to reach a next lactation, the event considered was culling, and cows that did reach a next calving were all 
censored. The time of censoring for all of these cows was $729 \mathrm{~d}$ after calving, which was $1 \mathrm{~d}$ after the last cow was culled during this lactation. For the analysis of calving interval, all cows that were culled during the lactation were excluded from the analysis, and thus no censored data were present. The effect of block was initially brought into the models, but models failed to converge. Therefore, it was decided to use the best available alternative to control variance, which was the effect of farm. For all of these models, the hazard ratio (HR) with 95\% confidence interval is reported. All figures were generated using SAS.

\section{RESULTS AND DISCUSSION}

The objective of the study was to evaluate the effects of a Ca-energy drink voluntarily consumed at calving on lactation performance (milk productivity) and lactation resilience (odds to reach a next lactation, and calving interval) for primiparous and multiparous cows. As the supplement consisted of several ingredients including $\mathrm{CaCO}_{3}$ and dextrose, as well as other minerals and vitamins, it should be clear that the effects observed cannot be entirely attributed to the Ca content or source, but could potentially be explained by these other nutrients. Quantitatively, the amount of energy provided by the supplement represented about 10 MJ. For a cow eating (on the first day after calving) $14 \mathrm{~kg}$ DM of a diet with a gross energy content of $19 \mathrm{MJ} / \mathrm{kg}$ of $\mathrm{DM}$, this additional energy supply of 10 MJ would represent less than 5\% of total gross energy intake. However, when compared with prophylactic oral drench of propylene glycol apply to prevent subclinical ketosis, this additional glucogenic energy supply may be regarded as relevant. Previous studies have indeed shown that amount of propylene glycol as low as 310 $\mathrm{g} / \mathrm{d}$ may reduce risk of subclinical and clinical ketosis (McArt et al., 2011). However, in contrast to our study, these types of application require repeated supplementation across several days (i.e., up to $13 \mathrm{~d}$ in McArt et al., 2011). As it is a single application, it seems unlikely that such a low energetic supply would explain the responses observed in this study. Long-term effects that would be observed in response to a 1-time supplementation are more likely to be due to a signaling effect at a critical time and, as such, Ca represents a good candidate to explain the results obtained. Nonetheless, other minerals or vitamins could also play a role.

\section{Voluntary Consumption of the Treatments}

Eighty-one percent of the CAE cows $(83.6 \%$ for primiparous and $80.0 \%$ for multiparous) and $50 \%$ of CON cows ( $55.1 \%$ for primiparous and $48.3 \%$ for multiparous) voluntarily consumed the treatment fully, demonstrating a difference $(P<0.01)$ in acceptance for voluntary consumption between the 2 treatments. Therefore, in addition to the intended and achieved difference in $\mathrm{Ca}$ supply between the 2 treatments, a consequence of this result is that cows in the CAE treatment also consumed a greater amount of water by treatment administration, suggesting greater palatability of $\mathrm{CAE}$ treatment as compared with CON treatment. These results are consistent with van Kuijk et al. [J. N. Wilms, J. B. Daniel, J. Martin-Tereso, Y. Han, S. van Kuijk (Trouw Nutrition R\&D, the Netherlands), A. Klop, and R. Goselink (Wageningen University, the Netherlands), unpublished data], where percentage of refusals were lower in cows receiving the same Ca-energy supplement against cows receiving warm water as a control. To our knowledge, the effects of water intake immediately after calving on milk productivity, health, and fertility have not been investigated previously, and it is unclear what role this extra amount of water consumed played in the results observed in this study.

\section{Milk Yield and Composition}

The effects of the treatment on milk yield and composition of the first 249 DIM are presented in Table 2. With the exception of a significant $(P=0.02)$ treatment by time interaction for milk fat yield, no significant differences in milk productivity could be detected between the 2 treatments for multiparous cows. The interaction for milk fat yield in multiparous cows indicated that cows fed CAE had greater milk fat yield between 100 and 149 DIM $(+68 \mathrm{~g} / \mathrm{d})$, whereas the rest of the lactation monitored in this study was not affected. A positive response restricted to this specific lactation stage was unexpected and difficult to explain. This result also contrasted with the second set of analyses (see Table 3 ), where no interaction was observed. For primiparous cows, milk yield, FPCM, and milk lactose yield tended to be increase $(+1.2 \mathrm{~kg} / \mathrm{d},+1.1 \mathrm{~kg} / \mathrm{d}$, and $+61 \mathrm{~g} / \mathrm{d}$, respectively), and milk protein yield $(+40 \mathrm{~g} / \mathrm{d})$ was significantly greater for CAE cows. In addition, SCS were reduced for primiparous cows, but not for multiparous cows. An interaction between treatment and time for SCC on primiparous cows was also observed, and indicated greater differences between 0 and 49 DIM and 100 and 149 DIM (difference between CAE and CON: -57 and -54 SCS, respectively) as compared with differences observed between 50 and 99 and 150 and 249 DIM (from -11 to -15 SCS). Decrease in milk SCC within the first 90 DIM were also reported with subcutaneous infusions of $\mathrm{Ca}$ at calving (Amanlou et al., 2016). However, in contrast to the present study, the effect was observed across parity groups (first, second, 
or third and above lactation groups). The analysis on residuals milk data confirmed the absence of effects in multiparous cows and the increase of FPCM and milk and component yields for primiparous cows receiving the Ca-energy supplement drinks (Table 3). Overall, this second set of analyses indicated that the administration of a Ca-energy supplement drink at calving improved milk yield and FPCM in primiparous cows by $1.5 \mathrm{~kg} / \mathrm{d}$ (i.e., 1.3 to -0.2 ) and $1.3 \mathrm{~kg} / \mathrm{d}$, respectively $(P \leq 0.02)$. Additionally, milk fat yield $(P=$ $0.04)$ and milk protein and lactose yields $(P \leq 0.01)$ were improved in primiparous cows by 49,57 , and 67 $\mathrm{g} / \mathrm{d}$, respectively. As multiparous are known to be more sensitive to subclinical hypocalcemia than primiparous cows (e.g., Venjakob et al., 2017), milk yield responses to the supplementation of the Ca-energy drink were unexpected. Was the amount of Ca too low for multiparous cows? Are other minerals or vitamins responsible for the milk responses? It is difficult to speculate at this stage for the underlying mechanism explaining these differential responses between parity groups. In response to oral Ca bolus, Leno et al. (2018) also reported a beneficial effect on milk yield for primiparous cows with BCS $>3.5$, whereas no milk yield improvement was reported for multiparous cows. A potential interaction with production potential within multiparous cows could also be a reason for the lack of milk response. Indeed, Martinez et al., (2016) reported that Ca supplementation was beneficial to milk yield in the first 30 DIM in multiparous cows of greater production potential, but detrimental to those with below average production potential. Similarly, another study (Oetzel and Miller, 2012) reported an increase in milk yield of $2.9 \mathrm{~kg} / \mathrm{d}$ (evaluated using the first test after calving) when highest producing multiparous cows were fed 2 Ca boluses at calving ( $43 \mathrm{~g}$ of $\mathrm{Ca}$, mainly from $\mathrm{CaCl}_{2}$ ). More recently, Valldecabres and Silva-del-Río (2021) reported that increase in milk yield and ECM yield in multiparous cows due to supplementation of oral $\mathrm{Ca}$ boluses after calving were conditional to previous lactation length. In that study, cows with the longest previous lactation (fourth quartile) had increased milk yield of $1.8 \mathrm{~kg} / \mathrm{d}$ across the first 3 monthly tests, whereas cows with the shortest previous lactation (first quartile) tended to have lower ECM yield $(-1.3 \mathrm{~kg} / \mathrm{d})$. In the present study, milk records and lactation length from

Table 2. Milk yield and composition of the first 249 DIM in dairy cows receiving a Ca-energy supplement drink or a control liquid for voluntary consumption at calving

\begin{tabular}{|c|c|c|c|c|c|}
\hline \multirow[b]{2}{*}{ Item } & \multicolumn{2}{|c|}{ Treatment $^{1}$} & \multirow[b]{2}{*}{ SEM } & \multicolumn{2}{|c|}{$P$-value ${ }^{2}$} \\
\hline & $\mathrm{CAE}$ & $\mathrm{CON}$ & & Treatment & Time \\
\hline \multicolumn{6}{|c|}{ Primiparous $(\mathrm{n}=140)$} \\
\hline Milk vield $(\mathrm{kg} / \mathrm{d})$ & 29.5 & 28.3 & 0.5 & 0.07 & $<0.01$ \\
\hline $\mathrm{FPCM}^{3}(\mathrm{~kg} / \mathrm{d})$ & 30.6 & 29.5 & 0.5 & 0.09 & $<0.01$ \\
\hline Fat $(g / d)$ & 1,248 & 1,207 & 19 & 0.13 & $<0.01$ \\
\hline $\mathrm{CP}(\mathrm{g} / \mathrm{d})$ & 1,029 & 989 & 15 & 0.03 & $<0.01$ \\
\hline Lactose (g/d) & 1,383 & 1,322 & 25 & 0.07 & $<0.01$ \\
\hline Fat $(\%)$ & 4.26 & 4.29 & 0.04 & 0.62 & $<0.01$ \\
\hline $\mathrm{CP}(\%)$ & 3.51 & 3.50 & 0.02 & 0.81 & $<0.01$ \\
\hline Lactose (\%) & 4.68 & 4.68 & 0.01 & 0.74 & $<0.01$ \\
\hline Urea (mg/dL) & 23.3 & 23.8 & 0.35 & 0.21 & $<0.01$ \\
\hline $\mathrm{SCS}^{4}$ & 1,517 & 1,547 & 13 & 0.06 & $<0.01$ \\
\hline \multicolumn{6}{|c|}{ Multiparous $(\mathrm{n}=336)$} \\
\hline Milk yield $(\mathrm{kg} / \mathrm{d})$ & 37.0 & 37.0 & 0.4 & 0.92 & $<0.01$ \\
\hline FPCM $(\mathrm{kg} / \mathrm{d})$ & 38.4 & 38.1 & 0.4 & 0.59 & $<0.01$ \\
\hline Fat $(\mathrm{g} / \mathrm{d})$ & 1,569 & 1,551 & 18 & 0.42 & $<0.01$ \\
\hline $\mathrm{CP}(\mathrm{g} / \mathrm{d})$ & 1,271 & 1,265 & 12 & 0.69 & $<0.01$ \\
\hline Lactose $(\mathrm{g} / \mathrm{d})$ & 1,691 & 1,689 & 20 & 0.94 & $<0.01$ \\
\hline Fat $(\%)$ & 4.31 & 4.26 & 0.04 & 0.38 & $<0.01$ \\
\hline $\mathrm{CP}(\%)$ & 3.46 & 3.46 & 0.02 & 0.95 & $<0.01$ \\
\hline Lactose (\%) & 4.57 & 4.56 & 0.01 & 0.17 & $<0.01$ \\
\hline Urea (mg/dL) & 22.7 & 22.4 & 0.22 & 0.24 & $<0.01$ \\
\hline SCS & 1,588 & 1,590 & 10 & 0.89 & $<0.01$ \\
\hline
\end{tabular}

\footnotetext{
${ }^{1}$ Treatments included a Ca-energy supplement drink (CAE; $\mathrm{n}=240 ; 45 \mathrm{~g}$ of $\mathrm{Ca}$ and dextrose, lactose, protein, fat, other minerals, and vitamins) or a placebo (CON; $\mathrm{n}=236 ; 100 \mathrm{~g}$ of cellulose and $20 \mathrm{~g}$ of dextrose) offered for voluntary consumption. Treatments were offered mixed in $20 \mathrm{~L}$ of water within $3 \mathrm{~h}$ after calving for a total duration of 15 min.

${ }^{2}$ Treatment $\times$ Time interaction were significant for SCC in primiparous cows $(P=0.05)$ and for milk fat yield in multiparous cows $(P=0.02)$.

${ }^{3} \mathrm{FPCM}=$ fat- and protein-corrected milk.

${ }^{4} \mathrm{SCS}=1,000+100 \times[2 \times \log (\mathrm{SCC} / 1,000)]$.
} 
the previous lactation were not available; consequently, it was not possible to study if high-producing cows or longer previous lactations were more likely to benefit from a Ca-energy supplement drink at calving. Overall, these data highlight the importance of characterizing cow-related factors (i.e., production potential, parity, BCS) in studies that would evaluate the effect of $\mathrm{Ca}$ supplementation at calving on milk yield and composition of subsequent lactation. Another limitation of the current study to explore potential interaction with other relevant factors was the lack of information on dry-cow management related to the prevention of milk fever.

\section{Incidence of Subclinical Ketosis}

The only health parameter that could be studied was incidence of subclinical ketosis, and this was done through an indirect proxy such as the use of milk acetone, BHBA, and milk fat-protein ratio, factors which have all been associated with this disorder (van der Drift et al., 2012a). Within the first 30 DIM, 15.1\% of CAE cows and $19.5 \%$ of CON cows were diagnosed with subclinical ketosis; however, this difference was not significant $(P=0.28 ; \mathrm{RR}=0.77$ with $95 \% \mathrm{CI}$ of 0.48-1.24). Surprisingly, this numerical difference was mainly driven by a significant difference observed for primiparous cows, for which the CAE treatment lowered the incidence of subclinical ketosis $(2.1 \%$ vs. $13.0 \%, P=0.03$; RR $=0.16$ with $95 \%$ CI of $0.02-1.27)$, whereas no effects were observed for multiparous cows. As expected, multiparous cows had a much greater incidence of subclinical ketosis $(21.2 \%)$ than firstlactation cows $(7.4 \%, P<0.01 ; \mathrm{RR}=2.84$ with $95 \%$ CI of 1.34-6.04). It should be mentioned that the model used in this study to diagnose cows with subclinical ketosis had some limitations. Indeed, this model was considered not suitable for individual detection of cows with ketosis due to a relatively large number of falsepositive test-day results (van der Drift et al., 2012b). This model evaluation was conducted over the first 60 DIM, and van der Drift et al. (2012b) suggested that false-positive test-day results would decrease if the model was restricted to the first 30 DIM only. This suggestion was followed in the current paper. However, as no evaluation of this model was conducted on this

Table 3. Residual milk yield and composition of the first 249 DIM in dairy cows receiving a Ca-energy supplement drink or a control liquid for voluntary consumption at calving

\begin{tabular}{|c|c|c|c|c|c|}
\hline \multirow[b]{2}{*}{ Item } & \multicolumn{2}{|c|}{ Treatment $^{1}$} & \multirow[b]{2}{*}{ SEM } & \multicolumn{2}{|c|}{$P$-value ${ }^{2}$} \\
\hline & $\mathrm{CAE}$ & $\mathrm{CON}$ & & Treatment & Time \\
\hline \multicolumn{6}{|c|}{ Residuals for primiparous $(\mathrm{n}=140)$} \\
\hline Milk yield $(\mathrm{kg} / \mathrm{d})$ & $1.32 *$ & -0.21 & 0.43 & $<0.01$ & 0.81 \\
\hline $\mathrm{FPCM}^{3}(\mathrm{~kg} / \mathrm{d})$ & $1.02^{*}$ & -0.27 & 0.42 & 0.02 & 0.27 \\
\hline Fat $(\mathrm{g} / \mathrm{d})$ & $35.6^{*}$ & -13.6 & 17.4 & 0.04 & 0.23 \\
\hline $\mathrm{CP}(\mathrm{g} / \mathrm{d})$ & $45.1^{*}$ & -11.4 & 13.1 & $<0.01$ & 0.86 \\
\hline Lactose $(\mathrm{g} / \mathrm{d})$ & $60.3^{*}$ & -6.6 & 19.9 & 0.01 & 0.68 \\
\hline Fat $(\%)$ & $-0.08^{*}$ & 0.00 & 0.03 & 0.08 & 0.01 \\
\hline $\mathrm{CP}(\%)$ & 0.01 & -0.02 & 0.02 & 0.29 & 0.40 \\
\hline Lactose $(\%)$ & 0.01 & 0.01 & 0.01 & 0.50 & 0.75 \\
\hline Urea $(\mathrm{mg} / \mathrm{dL})$ & $-0.54^{*}$ & 0.09 & 0.27 & 0.07 & 0.28 \\
\hline $\mathrm{SCS}^{4}$ & $-21.4^{*}$ & 16.3 & 11.5 & 0.01 & 0.98 \\
\hline \multicolumn{6}{|c|}{ Residuals for multiparous $(\mathrm{n}=336)$} \\
\hline Milk yield $(\mathrm{kg} / \mathrm{d})$ & $0.55^{*}$ & 0.32 & 0.28 & 0.52 & 0.06 \\
\hline FPCM $(\mathrm{kg} / \mathrm{d})$ & 0.32 & 0.10 & 0.26 & 0.52 & 0.33 \\
\hline Fat $(\mathrm{g} / \mathrm{d})$ & 7.2 & -5.3 & 11.8 & 0.54 & 0.66 \\
\hline $\mathrm{CP}(\mathrm{g} / \mathrm{d})$ & $17.6^{*}$ & 5.5 & 8.3 & 0.26 & 0.02 \\
\hline Lactose $(\mathrm{g} / \mathrm{d})$ & $27.6^{*}$ & 14.8 & 19.9 & 0.45 & 0.12 \\
\hline Fat $(\%)$ & -0.03 & -0.05 & 0.02 & 0.53 & 0.15 \\
\hline $\mathrm{CP}(\%)$ & -0.01 & -0.01 & 0.01 & 0.72 & $<0.01$ \\
\hline Lactose $(\%)$ & 0.01 & 0.00 & 0.00 & 0.40 & 0.07 \\
\hline Urea $(\mathrm{mg} / \mathrm{dL})$ & -0.29 & -0.11 & 0.15 & 0.36 & 0.55 \\
\hline SCS & -8.8 & -10.8 & 8.2 & 0.85 & 0.03 \\
\hline
\end{tabular}

${ }^{1}$ Treatments included a Ca-energy supplement drink (CAE; $\mathrm{n}=240 ; 45 \mathrm{~g}$ of Ca and dextrose, lactose, protein, fat, other minerals, and vitamins) or a placebo (CON; $\mathrm{n}=236 ; 100 \mathrm{~g}$ of cellulose and $20 \mathrm{~g}$ of dextrose) offered for voluntary consumption. Treatments were offered mixed in $20 \mathrm{~L}$ of water within $3 \mathrm{~h}$ after calving for a total duration of $15 \mathrm{~min}$.

${ }^{2}$ Treatment $\times$ Time interaction were significant for SCC in primiparous cows $(P=0.03)$.

${ }^{3} \mathrm{FPCM}=$ fat- and protein-corrected milk.

${ }^{4} \mathrm{SCS}=1,000+100 \times[2 \times \log (\mathrm{SCC} / 1,000)]$.

*Residuals that significantly $(P<0.05)$ differ from 0 . 
restricted period, subclinical ketosis results obtained in this study should be interpreted with caution. Due to the absence of reliable and accessible biomarkers, it was not possible to assess the effects of the oral CAE supplement on other calving-related disorders, such as milk fever, or on blood Ca concentrations. Previous experiments, using the same oral CAE supplement as in the present study, have shown that $\mathrm{CaCO}_{3}$ (45 g of $\mathrm{Ca}$ ) was able to maintain blood tCa concentrations for $24 \mathrm{~h}$ at greater concentrations when compared with an i.v. Ca infusion (13 g of Ca; Wilms et al., 2019), or an oral Ca bolus [43 g of Ca; J. N. Wilms, J. B. Daniel, J. Martin-Tereso, Y. Han, S. van Kuijk (Trouw Nutrition R\&D, the Netherlands), A. Klop, and R. Goselink (Wageningen University, the Netherlands), unpublished data]. Although effects of a management strategies on calving-related diseases are difficult to evaluate in commercial farms, an alternative is to evaluate an eventual effect on the odds to reach a next lactation and on calving interval, which reflect both cumulative health incidence and reproductive performance.

\section{Odds to Reach a Next Lactation and Calving Interval}

Survival probabilities for both groups are shown in Figure 1 in relation to days after calving. In total, $71.8 \%$ of CAE cows had a next calving (183 out of 255 cows; $84.0 \%$ for primiparous and $66.7 \%$ for multiparous), whereas $69.1 \%$ of CON cows did reach a next calving (172 out of 249 cows; $84.1 \%$ for primiparous and $63.3 \%$ for multiparous). The HR of 0.89 indicates cows from the CAE treatment had, at any given time during the lactation, $11 \%$ less probability to experience culling. However, this effect was not significant $(P=0.47)$, as illustrated by a wide $95 \%$ confidence interval (HR = 0.64-1.23), indicating that the true difference was between a $36 \%$ lower and a $23 \%$ higher probability to be culled. The interaction between treatment and parity group was also not significant $(P=0.81)$. However, an interaction was present $(P=0.01)$ for survival analysis, which studied time lapse to next calving (i.e., calving interval). Indeed, the treatments had significant effects on calving interval for first-lactation cows. Figure 2 il-

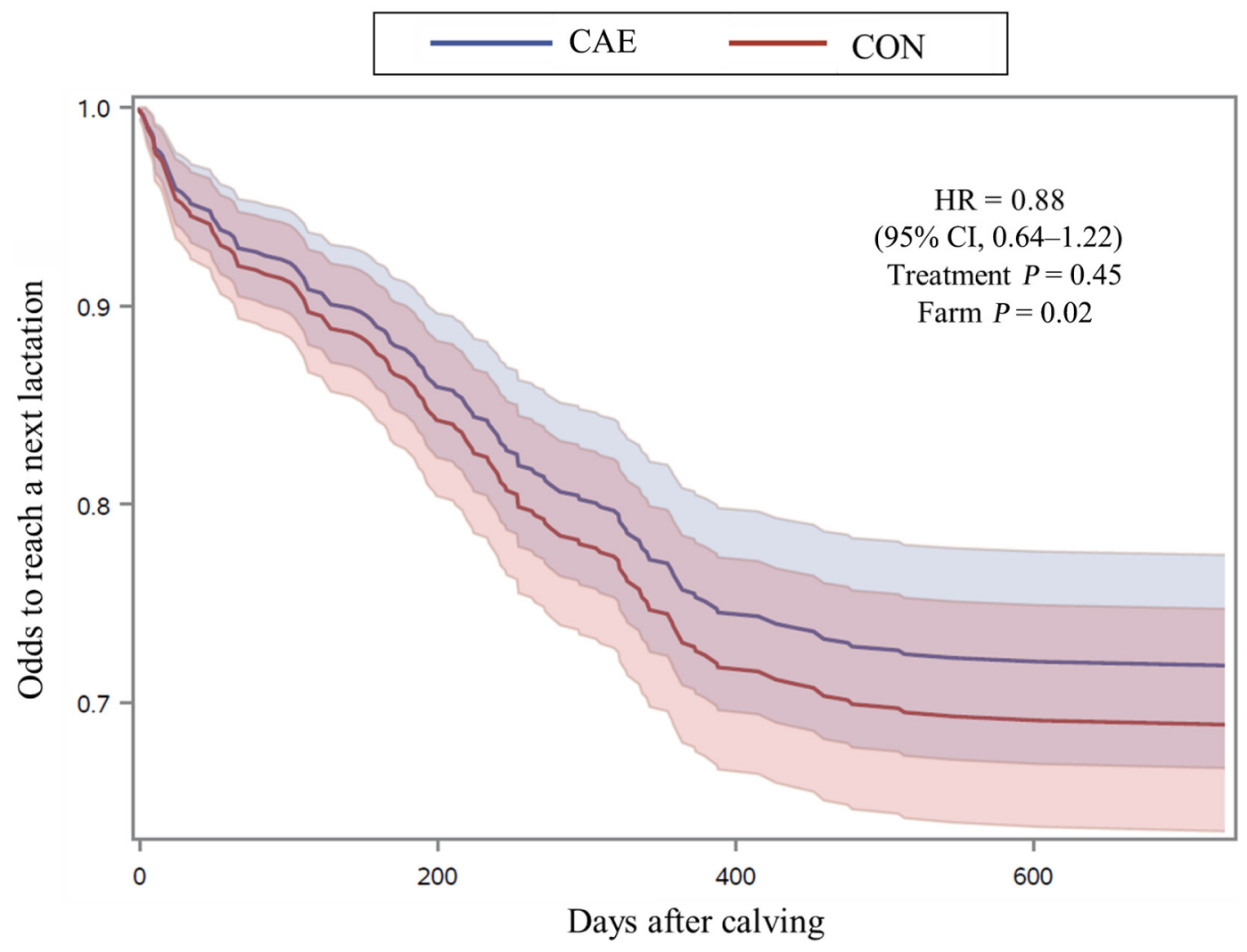

Figure 1. Culling analysis: probability that cows will remain in the herd, and thus avoid culling, in relation to days from calving for both treatments, including a Ca-energy supplement drink (CAE; $\mathrm{n}=255 ; 45 \mathrm{~g}$ of Ca and dextrose, lactose, protein, fat, other minerals, and vitamins) or a placebo (CON; $\mathrm{n}=249 ; 100 \mathrm{~g}$ of cellulose and $20 \mathrm{~g}$ of dextrose) offered for voluntary consumption. Treatments were offered mixed in $20 \mathrm{~L}$ of water within $3 \mathrm{~h}$ after calving for a total duration of $15 \mathrm{~min}$. No differences were observed between primiparous $(P=0.84)$ and multiparous $(P=0.42)$, so result of the analysis is displayed across parities. HR $=$ hazard ratio. 

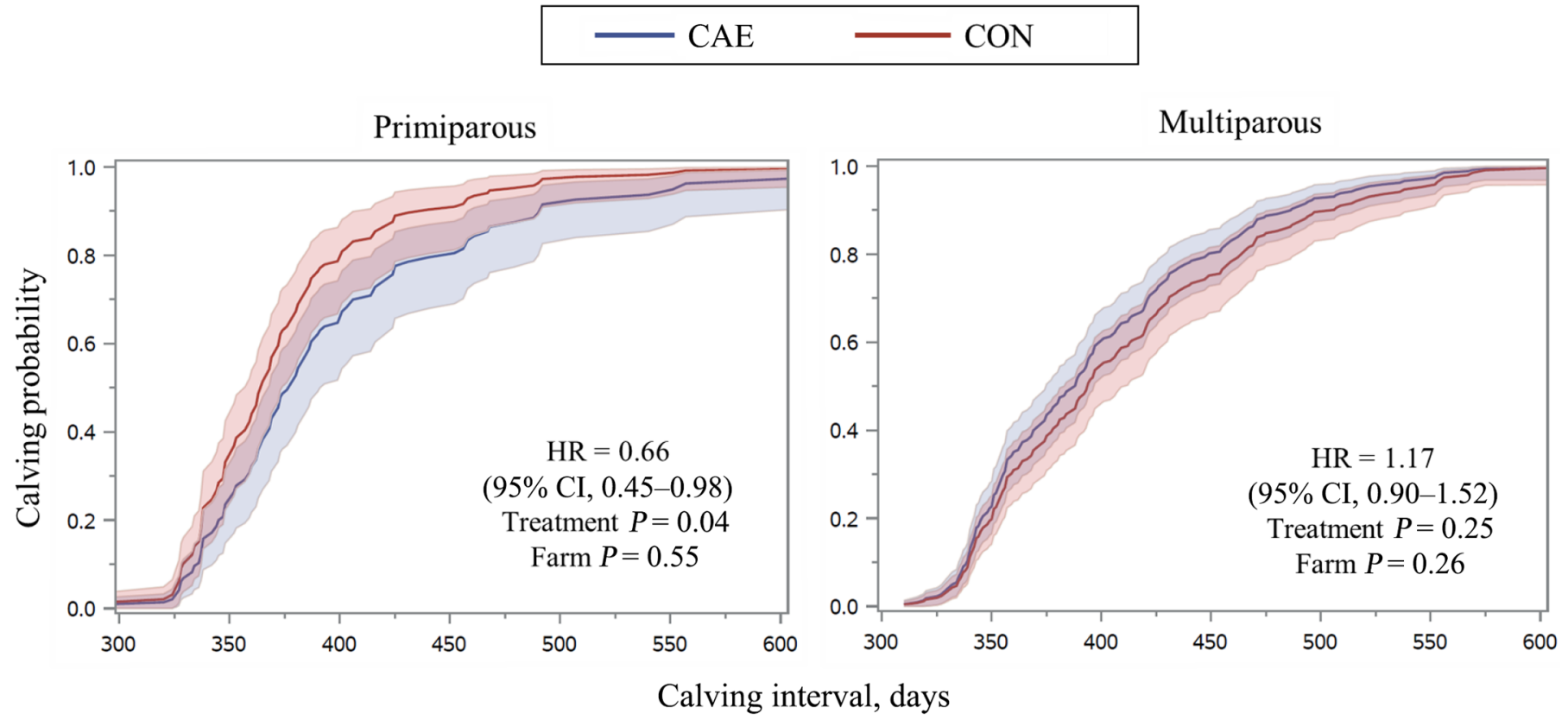

Figure 2. Calving interval analysis: probability of calving for cows that did reach a next calving, in relation to calving interval, for both treatments, including a Ca-energy supplement drink (CAE; $\mathrm{n}=183 ; 45 \mathrm{~g}$ of Ca and dextrose, lactose, protein, fat, other minerals, and vitamins) or a placebo (CON; $\mathrm{n}=172 ; 100 \mathrm{~g}$ of cellulose and $20 \mathrm{~g}$ of dextrose) offered for voluntary consumption to primiparous cows ( $\mathrm{n}=121)$ and to multiparous cows $(\mathrm{n}=234)$. Treatments were offered mixed in $20 \mathrm{~L}$ of water within $3 \mathrm{~h}$ after calving for a total duration of 15 min.

lustrates the cumulative probability of a next calving relative to the time from previous calving for the 2 parity groups. First-lactation cows that received the CAE treatment had a longer calving interval compared with cows from the CON treatment $(P=0.02)$. At 400 $\mathrm{d}$ after the previous calving in which the treatment was applied, $65 \%$ ( $\mathrm{CI}=52-75 \%$ ) of the $\mathrm{CAE}$ cows had a next calving, whereas $81 \%(\mathrm{CI}=69-88 \%)$ of the CON cows had calved already. Longer calving interval may be the result of reduced pregnancy rate per AI, as observed in Martinez et al. (2016). However, in contrast to this study, in which multiparous cows had an improved pregnancy to AI ratio, no effect of treatment on calving interval was observed for multiparous in our study. These results, and in particular the interaction observed with parity, are difficult to explain and deserve further study. This increase in calving interval for first-lactation cows is intriguing, especially coinciding with the observed reduction of subclinical ketosis and improvement in milk performance in this parity group.

\section{Using Herd Test-Day Model to Evaluate Management Strategy}

The use of the herd test-day model to correct for multiple fixed factors (i.e., farm effect, time effect, age at calving, parity, stage of lactation, breeding value) known to affect milk productivity was successful at in- creasing the experimental power, as indicated by lower standard error of the mean in Table 3 compared with Table 2 (i.e., 30\% lower SEM for milk yield in multiparous cows). This approach was powerful and able to detect subtle changes in milk production. In essence, such an approach could also be applied in absence of a control treatment. In this way, with a residual significantly different than zero, a positive or negative change in milk production could be established. In this specific case, it is remarkable that least squares means residuals of milk yield, FPCM, and milk component yields of primiparous cows obtained for the CAE treatment were all different from zero ( $P$-values not shown). In contrast, none of the residuals from the CON cows were significantly different from zero. These differences from zero correlate very well with the contrast between the 2 treatments (see $P$-values from Table 3 ). The exception of these concordances between the 2 approaches can be found for milk yield, milk lactose, and milk protein yield of multiparous cows. These residuals were all different from 0 , whereas differences with the CON treatment were not significant $(P \geq 0.26$, Table 3$)$. It should be noted that only the use of a prospective randomized design such as the one used in this study, as well as contrasting the treatment with a control, allows inference of a causal effect of treatment on milk production. Nevertheless, the use of herd test-day model to correct for multiple fixed effects known to affect milk produc- 
tivity represents a promising approach to evaluate the effect of a nutritional intervention on milk yield and composition in commercial farms.

\section{CONCLUSIONS}

Responses to the Ca-energy supplement drink at calving were highly influenced by parity. None of the outcomes evaluated in this study (milk yield and composition, odds to reach a next lactation, calving interval, subclinical ketosis) were affected by the supplement on multiparous cows. However, for supplemented primiparous cows, milk and components yields were increased, resulting in 1.1 to $1.3 \mathrm{~kg}$ of extra FPCM up to 249 DIM (depending on the method used to evaluated the response). Additionally, primiparous cows fed the supplement were less likely to be diagnosed with subclinical ketosis, but had greater calving interval. The use of prospective randomized controlled designs in combination with herd test-day models is a promising approach to demonstrate causal effects of nutritional interventions in commercial farms.

\section{ACKNOWLEDGMENTS}

The study was funded by Trouw Nutrition R\&D (Amersfoort, the Netherlands). The authors thank Mireille van Empel and Chantal van Den Hoven (Trouw Nutrition R\&D) for their technical assistance, as well as Pedro Vessies and Gerben de Jong from CRV to support us with statistical analysis. The authors of this paper are employed by Trouw Nutrition, a company with commercial interests in the oral $\mathrm{Ca}$ supplement included in the study. Trouw Nutrition R\&D adheres to the principles of the European Code of Conduct for Research Integrity (Drenth, 2012). The authors have not stated any other conflicts of interest.

\section{REFERENCES}

Amanlou, H., A. P. Akbari, N. E. Farsuni, and N. Silva-del-Río. 2016. Effects of subcutaneous calcium administration at calving on mineral status, health, and production of Holstein cows. J. Dairy Sci. 99:9199-9210. https://doi.org/10.3168/jds.2015-10844.

Blanc, C. D., M. Van der List, S. S. Aly, H. A. Rossow, and N. Silvadel-Río. 2014. Blood calcium dynamics after prophylactic treatment of subclinical hypocalcemia with oral or intravenous calcium. J. Dairy Sci. 97:6901-6906. https://doi.org/10.3168/jds.2014-7927.

Caixeta, L. S., P. A. Ospina, M. B. Capel, and D. V. Nydam. 2017. Association between subclinical hypocalcemia in the first 3 days of lactation and reproductive performance of dairy cows. Theriogenology 94:1-7. https://doi.org/10.1016/j.theriogenology.2017.01 .039 .

Chapinal, N., M. Carson, T. F. Duffield, M. Capel, S. Godden, M. Overton, J. E. P. Santos, and S. J. LeBlanc. 2011. The association of serum metabolites with clinical disease during the transition period. J. Dairy Sci. 94:4897-4903. https://doi.org/10.3168/jds $.2010-4075$.
Coulon, J. B., L. Pérochon, and F. Lescourret. 1995. Modelling the effect of the stage of pregnancy on dairy cows' milk yield. Anim. Sci. 60:401-408. https://doi.org/10.1017/S1357729800013278.

de Roos, A. P. W., A. G. F. Harbers, and G. de Jong. 2004. Random herd curves in a test-day model for milk, fat, and protein production of dairy cattle in the Netherlands. J. Dairy Sci. 87:2693-2701. https://doi.org/10.3168/jds.S0022-0302(04)73396-2.

de Roos, A. P. W., H. J. C. M. van den Bijgaart, J. Hørlyk, and G. de Jong. 2007. Screening for subclinical ketosis in dairy cattle by Fourier transform infrared spectrometry. J. Dairy Sci. 90:1761-1766. https://doi.org/10.3168/jds.2006-203.

Drenth PJ. 2012. A European code of conduct for research integrity. Promoting Research Integrity in a Global Environment. 161. ALLEA (All European Academies).

Goff, J. P. 1999. Treatment of calcium, phosphorus, and magnesium balance disorders. Vet. Clin. North Am. Food Anim. Pract. 15:619-639. https://doi.org/10.1016/S0749-0720(15)30167-5.

Goff, J. P., and R. L. Horst. 1993. Oral administration of calcium salts for treatment of hypocalcemia in cattle. J. Dairy Sci. 76:101-108. https://doi.org/10.3168/jds.S0022-0302(93)77328-2.

ISO. 1999. ISO 1211/IDF 1: Milk-Determination of fat contentGravimetric method (reference method). International Organization for Standardization.

ISO. 2001. ISO 8968-1/IDF 20-1: Milk-Determination of nitrogen content-Part 1: Kjeldahl method. International Organization for Standardization.

Jawor, P. E., J. M. Huzzey, S. J. LeBlanc, and M. A. G. Von Keyserlingk. 2012. Associations of subclinical hypocalcemia at calving with milk yield, and feeding, drinking, and standing behaviors around parturition in Holstein cows. J. Dairy Sci. 95:1240-1248. https://doi.org/10.3168/jds.2011-4586.

Leno, B. M., R. C. Neves, I. M. Louge, M. D. Curler, M. J. Thomas, T. R. Overton, and J. A. A. McArt. 2018. Differential effects of a single dose of oral calcium based on postpartum plasma calcium concentration in Holstein cows. J. Dairy Sci. 101:3285-3302. https: //doi.org/10.3168/jds.2017-13164.

Martinez, N., C. A. Risco, F. S. Lima, R. S. Bisinotto, L. F. Greco, E. S. Ribeiro, F. Maunsell, K. Galvão, and J. E. P. Santos. 2012. Evaluation of peripartal calcium status, energetic profile, and neutrophil function in dairy cows at low or high risk of developing uterine disease. J. Dairy Sci. 95:7158-7172. https://doi.org/10 $.3168 /$ jds.2012-5812.

Martinez, N., L. D. P. Sinedino, R. S. Bisinotto, R. Daetz, C. A. Risco, K. N. Galvão, W. W. Thatcher, and J. E. P. Santos. 2016. Effects of oral calcium supplementation on productive and reproductive performance in Holstein cows. J. Dairy Sci. 99:8417-8430. https:/ /doi.org/10.3168/jds.2015-10529.

McArt, J. A. A., and R. C. Neves. 2020. Association of transient, persistent, or delayed subclinical hypocalcemia with early lactation disease, removal, and milk yield in Holstein cows. J. Dairy Sci. 103:690-701. https://doi.org/10.3168/jds.2019-17191.

McArt, J. A. A., D. V. Nydam, P. A. Ospina, and G. R. Oetzel. 2011. A field trial on the effect of propylene glycol on milk yield and resolution of ketosis in fresh cows diagnosed with subclinical ketosis. J. Dairy Sci. 94:6011-6020. https://doi.org/10.3168/jds.2011 $-4463$.

Melendez, P., G. A. Donovan, C. A. Risco, R. Littell, and J. P. Goff. 2003. Effect of calcium-energy supplements on calving-related disorders, fertility and milk yield during the transition period in cows fed anionic diets. Theriogenology 60:843-854. https://doi.org/10 .1016/S0093-691X(03)00103-1.

Neves, R. C., B. M. Leno, K. D. Bach, and J. A. A. McArt. 2018. Epidemiology of subclinical hypocalcemia in early-lactation Holstein dairy cows: The temporal associations of plasma calcium concentration in the first 4 days in milk with disease and milk production. J. Dairy Sci. 101:9321-9331. https://doi.org/10.3168/ jds.2018-14587.

Oetzel, G. R., and B. E. Miller. 2012. Effect of oral calcium bolus supplementation on early-lactation health and milk yield in commercial dairy herds. J. Dairy Sci. 95:7051-7065. https://doi.org/ $10.3168 /$ jds.2012-5510. 
Østergaard, S., and T. Larsen. 2000. Associations between blood calcium status at calving and milk yield in dairy cows. J. Dairy Sci. 83:2438-2440. https://doi.org/10.3168/jds.S0022-0302(00)75134 -4 .

Rajala-Schultz, P. J., Y. T. Gröhn, and C. H. McCulloch. 1999. Effects of milk fever, ketosis, and lameness on milk vield in dairy cows. J. Dairy Sci. 82:288-294. https://doi.org/10.3168/jds.S0022 -0302(99)75235-5.

Reinhardt, T. A., J. D. Lippolis, B. J. McCluskey, J. P. Goff, and R. L. Horst. 2011. Prevalence of subclinical hypocalcemia in dairy herds. Vet. J. 188:122-124. https://doi.org/10.1016/j.tvjl.2010.03.025.

Roberts, T., N. Chapinal, S. J. LeBlanc, D. F. Kelton, J. Dubuc, and T. F. Duffield. 2012. Metabolic parameters in transition cows as indicators for early-lactation culling risk. J. Dairy Sci. 95:30573063. https://doi.org/10.3168/jds.2011-4937.

Rowlands, G. J., and S. Lucey. 1986. Changes in milk yield in dairy cows associated with metabolic and reproductive disease and lameness. Prev. Vet. Med. 4:205-221. https://doi.org/10.1016/0167 $-5877(86) 90024-3$.

Sampson, J. D., J. N. Spain, C. Jones, and L. Carstensen. 2009. Effects of calcium chloride and calcium sulfate in an oral bolus given as a supplement to postpartum dairy cows. Vet. Ther. 10:131-139.

Sawalha, R. M., J. F. Keown, S. D. Kachman, and L. D. Van Vleck. 2005. Evaluation of autoregressive covariance structures for testday records of Holstein cows: Estimates of parameters. J. Dairy Sci. 88:2632-2642. https://doi.org/10.3168/jds.S0022-0302(05)72940 -4 .

Stevenson, M. A., N. B. Williamson, and D. W. Hardon. 1999. The effects of calcium supplementation of dairy cattle after calving on milk, milk fat and protein production, and fertility. N. Z. Vet. J. 47:53-60. https://doi.org/10.1080/00480169.1999.36111.

Thilsing-Hansen, T., R. J. Jørgensen, and S. Østergaard. 2002. Milk fever control principles: A review. Acta Vet. Scand. 43:1-19. https: //doi.org/10.1186/1751-0147-43-1.
Valldecabres, A., and N. Silva-del-Río. 2021. Effects of postpartum oral calcium supplementation on milk yield, milk composition, and reproduction in multiparous Jersey and Jersey $\times$ Holstein crossbreed cows. J. Dairy Sci. 104:795-805. https://doi.org/10.3168/ jds.2020-19079.

van der Drift, S. G. A., R. Jorritsma, J. T. Schonewille, H. M. Knijn, and J. A. Stegeman. 2012b. Routine detection of hyperketonemia in dairy cows using Fourier transform infrared spectroscopy analysis of $\beta$-hydroxybutyrate and acetone in milk in combination with test-day information. J. Dairy Sci. 95:4886-4898. https://doi.org/ 10.3168/jds.2011-4417.

van der Drift, S. G. A., K. J. E. van Hulzen, T. G. Teweldemedhn, R. Jorritsma, M. Nielen, and H. C. M. Heuven. 2012a. Genetic and nongenetic variation in plasma and milk $\beta$-hydroxybutyrate and milk acetone concentrations of early-lactation dairy cows. J. Dairy Sci. 95:6781-6787. https://doi.org/10.3168/jds.2012-5640.

Venjakob, P. L., S. Borchardt, and W. Heuwieser. 2017. Hypocalcemia - Cow-level prevalence and preventive strategies in German dairy herds. J. Dairy Sci. 100:9258-9266. https://doi.org/10.3168/ jds.2016-12494.

Wilms, J., G. Wang, J. Doelman, M. Jacobs, and J. Martín-Tereso. 2019. Intravenous calcium infusion in a calving protocol disrupts calcium homeostasis compared with an oral calcium supplement. J. Dairy Sci. 102:6056-6064. https://doi.org/10.3168/jds.2018-15754.

\section{ORCIDS}

Jean-Baptiste Daniel @ https://orcid.org/0000-0001-7627-3708 Juliette N. Wilms ำ https://orcid.org/0000-0003-1725-1087 Javier Martín-Tereso @ https://orcid.org/0000-0002-6757-4629 